\title{
THE APPLICABILITY OF GEOMETRICAL GAMES IN DESIGNING MODULAR HOUSING SOLUTIONS
}

\author{
Krisztián Palócz ${ }^{1 *}$, Vilmos Katona ${ }^{2}$
}

\footnotetext{
${ }^{1}$ József Cziráki Doctoral School of Wood Sciences and Technologies, Károly Simonyi Faculty of Engineering, Wood Sciences and Applied Arts, University of Sopron, 4 Bajcsy-Zsilinszky utca, Sopron, 9400, Hungary.

E-mail: krisztian.palocz@gmail.com

2 Institute of Applied Arts, Károly Simonyi Faculty of Engineering, Wood Sciences and Applied Arts, University of Sopron, 32 Deák tér, Sopron, 9400, Hungary.

E-mail: katona.vilmos@uni-sopron.hu

*corresponding author
}

\begin{abstract}
The purpose of this paper is to outline an innovative modular housing system based on geometric regularities, which responds to the issues raised by urbanization, the principles of environmental awareness, and the model of a sustainable city. The starting point of the analysis of wood-based systems is analysing the variations of elements obtained by repeating and assembling regular flat joints for filling the planar and the spatial. The following step is to model real spatial situations. According to the principal idea, geometric principle based logic games provide a pattern for designing modular housing units or systems. Although inherent in the classification and variation of the same elements, the system has a high degree of freedom and flexibility due to its nature. Multidimensional vertical spaces provide the opportunity to maximize the space given, while the openness and the flexibility of the system, the current character of the city, neighbourhood features remain - moreover, its implementation is flexible, adaptive, and customizable.
\end{abstract}

Keywords: gamification, modular architectural system, polycubes, sustainable city, urban stratification model.

JEL: C21, C25, L74, R23, R31 


\section{INTRODUCTION}

\subsection{The topic of the research}

The impact of urbanization in the daily lives of city dwellers can be traced in both structural and qualitative terms: due to the decrease in home time, climbing land prices and the changing social structure, small apartments are coming to the fore, which have to meet increased demands. The main area of our research is the examination and development of the technological, structural and design issues of the unit module and its multiples. Although my research is more about architectural design, the nature of the project (i.e., a prefabricated, modular and flexible system) can be parallel with the principles of industrial design at several points.

Our survey started with analyzing the variations of the elements obtained by sorting and assembling the plane figures and space elements that are suitable for filling the planar and the spatial, however, the experience gained was put into practice in the spatial organization of modular architectural design. The starting point of the design is a linear element and a spatial element associated with one another - in our case a column or a cube. Thus the system designed, although it is based on the sorting and variation of the same elements, has a high degree of freedom and flexibility due to its nature.

\subsection{Methodology}

The research process begins with the survey of empirical and consensual realities related to the subject, through different sciences (e.g., sociology, demography, climatology, applied mathematics, urbanism, semiotics, etc.).

Interdisciplinarity is indispensable due to the multidisciplinary nature of research, and that is reinforced by the "holistic approach". The distinction between deductive and inductive logic is an important element in setting up hypotheses and drawing conclusions. In the course of deductive theory we applied the method of "intersubjectivity" and the study of paradigms and paradigm shift. We mostly relied on the method of primed theory, field exploration and content analysis of inductive methods. Gamification is often thought of as the outcome of a project, however this method can also be applied in the conceptual design phase for making design concept, simulation and testing. 


\section{OVERVIEW}

\subsection{Traditional Japanese heritage}

In a complete guide to modern architecture (Jeanneret, 1923), Le Corbusier's Five Points of Architecture ${ }^{1}$ reveals a clear Japanese influence. The basic structure of the traditional Japanese machiya townhouse is the wooden framework. The floor is a special doublebottomed structure: at the bottom you can find the ground floor, which is built on the floor of almost half a meter high. This wooden floor is covered with mattress or bamboo mattresses, so-called tatami. The arrangement of these modular units ${ }^{2}$ determines the floor area and the layout of the house (Mitsuru, 1985).

\subsection{Modular approach to 20th century architecture}

One of the typical examples of post-war architecture is that Kisho Kurokawa's apparently irregular set of cells is based on the vision of metabolism. According to its theory, the city is a system of coherent, mobile, flexible cell-like elements. Kurokawa admits that urban buildings should induce the development of the individual through their spaces and means (Perényi, et al., 2013). His theory is related to Le Corbusier's concept of "the machine for living in", and the spirit of the phalanstery is reflected alike. The previously mentioned Capsule Tower of Nagakin is a sample building of the so-called capsule architecture, in which the highly equipped capsules are actually minimum-sized living spaces that can still guarantee the individual's living conditions. He applied the principle of connection, which means that housing cells are connected to the central tower of mechanical engineering and transport (Frampton, 2009).

\footnotetext{
${ }^{1}$ Le Corbusier developed a set of architectural principles that dictated his technique, which he called the Five Points of Architecture: (1) Pilotis: Replacement of supporting walls by a grid of reinforced concrete columns that bears the structural load is the basis of the new aesthetic. (2) The free designing of the ground plan (the absence of supporting walls) means the house is unrestrained in its internal use. (3) The free design of the façade (separating the exterior of the building from its structural function) sets the façade free from structural constraints. (4) Ribbon window. (5) Roof gardens on a flat roof can serve a domestic purpose while providing essential protection to the concrete roof (Cohen, 2005).

${ }^{2}$ The standard ken covers a tatami length and half a tatami width, in fact which is the size of a lying area. The most commonly used tatami size is used in Kyoto: $0.95 \times 1.91 \mathrm{~m}$.
} 


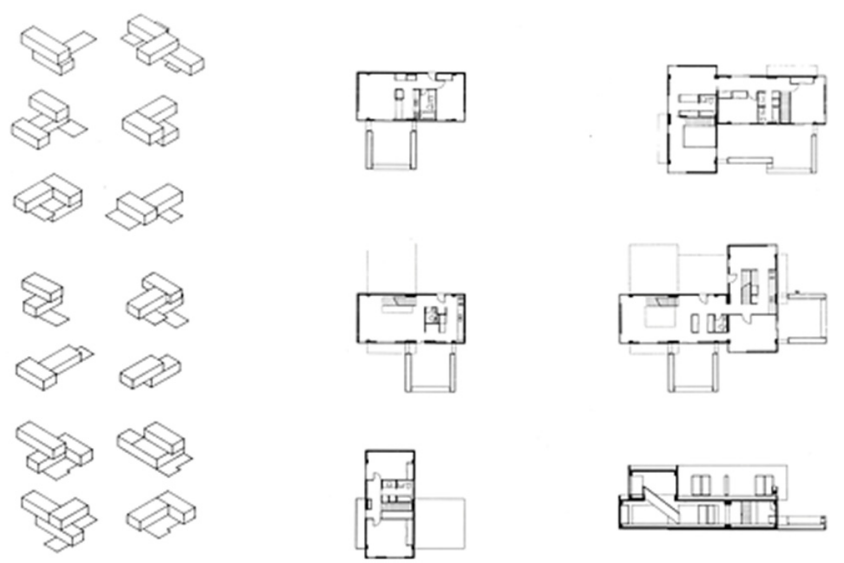

Figure 1: Moshe Safdie's Habitat 67 modular units, Montreal, Canada, 1967. (Source: https://i.pinimg.com/originals/92/bf/00/92bf005489cbda2e3ae2502b6fb3933d.gif)

Montreal's Habitat 67 is another excellent example of the same movement. The pilot project took place in the 1967 Montreal World Exhibition. The aim of the project was to create cheap and easy-to-build modular homes that are accessible to anyone. The solution for residential modules of the right size and function was found in the prefabricated construction technology. The modules are $11.7 \times 5.3 \times 3.0 \mathrm{~m}$ volumes, which are loosely placed on top of each other. The building complex mostly resembles a loose, pyramidlike space made of wooden blocks built randomly by children. Nonetheless, the upright, pyramid-shaped design is a thoughtful, thorough work of design. Only the kitchens and the bath units of the 15 types with different sizes and layouts are congruent. The apartments are two-, three-, and four-room units, mainly two-storey units, to which roof gardens are connected (French, 2006; Fig. 1).

\subsection{Redefining urban spaces}

In the past decades, the phenomenon of globalization is closely related to the spreading and dominance of telecommunication devices. As a consequence, the local nature of architecture is increasingly pushed into the background, while the global character is coming to the fore. As a result of this process, the number of urban inhabitants seem to grow, and, in parallel, the expansion of suburban territories is increasing, which has an impact on commuting, fuel consumption and car use. At the end of the 1960s, topography and sustainability gradually became the focus of architecture. 


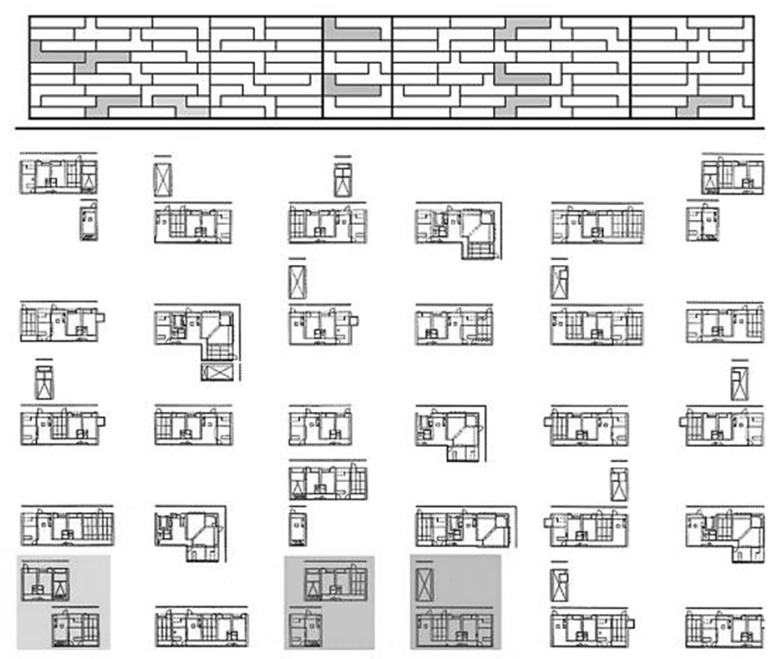

Figure 2: SANAA's Kitagata house types and layouts of apartments, Kitagata, Japan, 2000. (Source: http://1.bp.blogspot.com/-

PWFglJ6Ml1k/VfTsfrYzAiI/AAAAAAAAADA/j517XoquMlk/s1600/fachada\%2Btipos.JPG)

Vittorio Gregotti (1966) emphasized the importance of integrating man-made environment and natural forms in his book The Territory of Architecture. Approximately one decade later, Renzo Piano and Richard Rogers designed Pompidou Centre in Paris resulting in huge professional and public debates. The building is one of the extreme manifestations of open, flexible, and adaptive architecture (Frampton, 2009).

Contemporary architects are giving different answers to today's challenges. Some of them are looking for the individual within the building complexes (MVRDV: Silodam, Amsterdam), while others consider finding the answer in full anonymity (SANAA: Kitagata House, Kitagata, Japan). The solutions can be influenced by the architect's creed as well as the social, cultural and economic characteristics of the place. In addition to this, more and more attention is paid to mapping the real needs of the residents and the use of participative design methods based on extensive communication (Perényi, et al., 2013).

Kazuyo Sejima's Kitagata Residential House follows the principle of modularity. The basic module, however, is not the apartment, but the room (there are $2.6 \times 4.8 \times 2.6 \mathrm{~m}$ rooms next to each other). The basic modules, though of the same size, can be defined with four basic functions: the bedroom, the living room, the sacred room (tatami room), and the open room (terrace). Apartments of different sizes have at least 4 different combinations of units (up to 7 units with all 4 basic types, see Fig. 2). The terrace room 
can also be defined as a basic unit, so it is not an attached element but an open room occupying the entire building width. Moreover, it is in direct contact with the corridor (functioning as a common area) running along the façade of the lane-type building (Lenk, 2015).

In the Silodam project in Amsterdam, the architects sought to avoid the traditional horizontal division of residential buildings, but redefine the urban space. As a result, a three-dimensional urban space with all the typical features of a neighbourhood was born, and its appearance looks much more like a container-laden barge than an urban condominium (Fig. 3).

The starting point of MVRDV's plan was to create the diversity of the widest variety of homes. The concept mixes low-income families, older residents, artists, well-doing citizens with office workers and transit workers staying in rentable apartments. The 157 apartments on ten levels are divided into 15 different types, thus the units of the closer neighbourhoods can be defined clearly on the exterior façade thanks to their different materials, colours and characters. The public spaces of the building are scattered around: the harbour is situated at the bottom, while the restaurant and the communal terrace are on the higher levels. The rooftop has a terrace as well. Layouts and interior designs are surprisingly varied: flats, duplex and even triplex apartment. The location of the building is also uncommon: it is floating above the water along one of the harbour piers of Amsterdam (Metz, 2003; Perényi, et al., 2013).

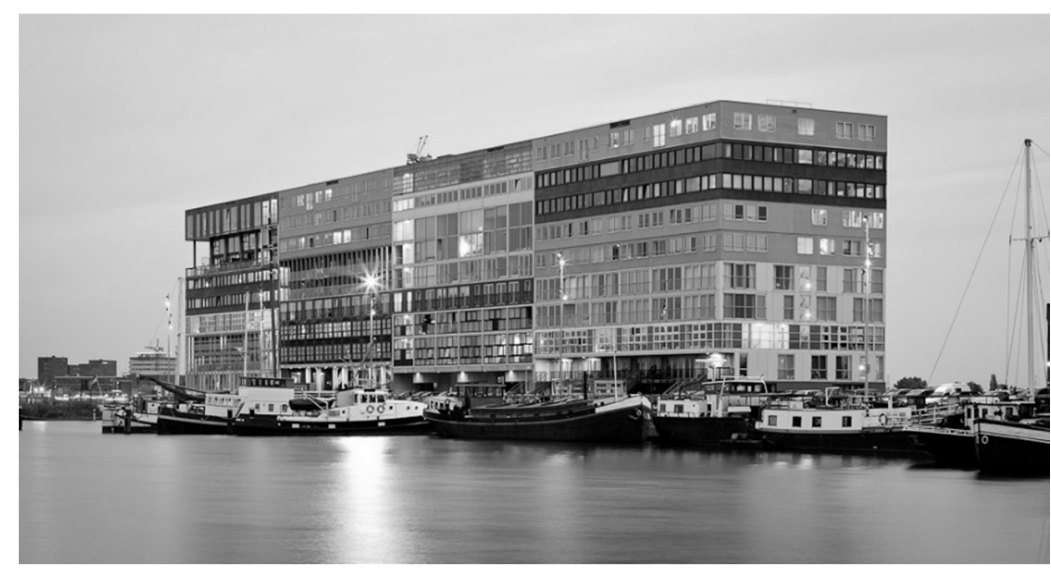

Figure 3: MVRDV's Silodam, Amsterdam, The Netherlands, 2003. (Source: https://i.pinimg.com/originals/3a/38/e2/3a38e24fff6346eee33ac693e25d5ade.jpg) 
The concept of Beijing's International Horticultural Expo 2019 designed by Penda Architectural Studio was based on modular units likewise. The site if the so-called Thousand Yards exhibition center is over $30,000 \mathrm{~m}^{2}$. It has a breezy, diverse, village-like character that differs significantly from the typical expo pavilions. It is full of plants, winding paths, and there are pavilions of different sizes scattered to different points of the overall orthogonal grid. This feature encourages the visitor to explore and discover the site. Winding, zigzag routes, hidden details and the unpredictability of the complex offer new surprises. Unexpected playgrounds, ponds, vegetable gardens, and tea houses may appear in different places. At the very centre of the net, there is an amoeba-shaped park, and that is surrounded by irregularly arranged pavilions with different functions. By the way, the grid was designed according to the ancient Chinese design, using an $8 \times 8 \mathrm{~m}$ module (Wang, 2017; Fig. 4).

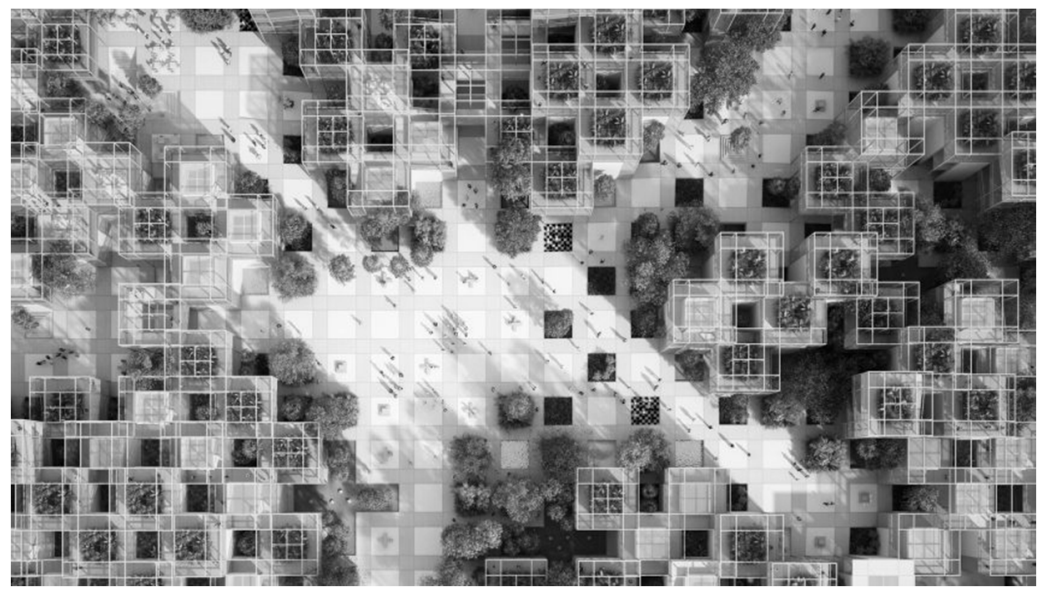

Figure 4: Penda Architectural Studio's complex for the International Horse Culture Expo, Beijing, China, 2019. (Source: https://inhabitat.com/penda-unveils-temporary-nature-filled-village-for-the-beijinghorticultural-expo)

In April 2017, two young designers of the Atelier L Studio, Beomki Lee and Chang Kyu Lee presented their Instant City: Living Air-Right project, which examines affordable housing solutions based on a state-owned support system over existing buildings in downtown area of New York City. In this area, we meet the exceptionally high priority housing problems of modern metropolises. We should know how, and by what means a sufficient number of new rental units can be built on a relatively small area.

New York City, where more than $75 \%$ of inhabitants live in rental apartments, has seen a real estate shortage several times over the last decade. Nevertheless, the Instant City 
offers an affordable solution to this burning issue in the new architectural model combined with state programs. The proposal does not only plan to build a sufficient number of rental units, but also provides spaces for community activities and solutions for redesigning urban transport. The concept encourages multi-dimensional interactions based on a vertical city model, integrating spaces related to housing, work, social and leisure activities.

Flexibility, adaptability and customization are essential for the model, since vertical architectural character may alter through each apartment, block and city neighbourhood. On top of that, Instant City offers a new type of community platform, called living surfaces, that is, communal spaces are scattered all along the grid to cover a number of community functions. They encourage users (residents, workers, visitors, etc.) to build social and cultural networks (Lee, 2017).

\section{INVESTIGATION OF SPATIAL LOGIC GAMES BASED ON GEOMETRIC PRINCIPLE}

\subsection{Gamification}

Gamification is the method of implementation of game-design elements and game principles in non-game contextual situation (Huotari, 2012). Game studies are based on the modern study of play by the Dutch historian Johan Huizinga (1949). ${ }^{3}$ Jesper Juul Danish psychologist describes a game as "a rule-based formal system with a variable and quantifiable outcome, where different outcomes are assigned different values, the player exerts effort in order to influence the outcome, the player feels attached to the outcome, and the consequences of the activity are optional and negotiable" (Juul, 2003).

\subsection{Filling the plane}

\subsubsection{Mathematical parquet}

The history of the issue of filling the plane (parquet flooring) is almost the same as the history of architecture. The floors of the buildings were initially made of flat pieces of

\footnotetext{
${ }^{3}$ Huizinga's book Homo Ludens, published originally by Wolters-Noordhoff cop. in Groningen, 1938, describes play as a free and meaningful activity, accomplished for its own sake, segregated from the requirements of practical life, and bound by rules defined in advance (cf. Rodriguez, 2006).
} 
stone that were adjacent to each other. Later, the stones were formed so that the biggest possible area of the floor shall be covered with the minimum gap between the stones (Reiman, 1999). Thus, mathematical parquet is the method of perfect plane covering with single layer figures.

Geometric patterns for such a covering can be traced back to four basic operations (vertical and horizontal reflection, rotation and glide) or variations thereof: repetition, horizontal reflection, glide reflection, vertical reflection, rotation by $180^{\circ}$, horizontal and vertical reflections, rotation and vertical glide (Bérczi, 1990).

\subsubsection{Polyominoes}

The elements of combinatorial games, unlike tangram puzzles, are not generated by splitting up, but by assembling. The pioneer of this game type was the American mathematician Solomon W. Golomb, who has made several mathematicians think theoretically about elementary sets of regular shapes, and their combinations (Gal, 2008). Golomb's polyminoes dealt with elements of squares. The simplest of these fused elements is the domino of two squares. There is only one type of domino, while the trio of three squares can be combined in two ways. From the four squares of tetrominoes, we can create five basic elements. These elements can be familiar to those found in Tetris.

Pentominoes are formed by fusing five squares, and there are exactly 12 different arrangements to lay them out. In 1953 and 1965, Golomb fully described polyominoes, and during the following decades, he listed a number of new problems in addition to summarizing his results (Golomb, 1996). Martin Gardner, the most well-known promoter of mathematical games, has also published several articles on the subject in Scientific American. Gardner stated, for example, that the $3 \times 5$ (15) unit rectangle is the smallest shape we can set up of pentominoes. Since there are 12 different pentomino elements, given that we use all of them, the biggest rectangle to set up is a $12 \times 5$ (60) unit rectangle (Gardner, 1966; Fig. 5). 

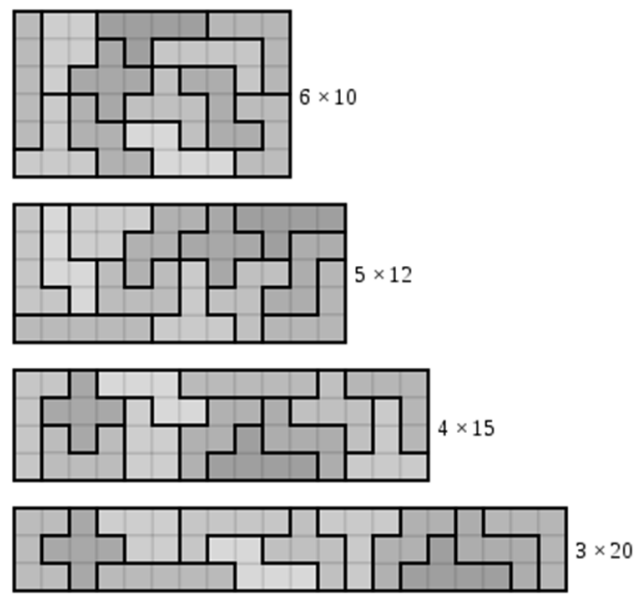

Figure 5: Rectangles of 60 units of 12 different pentomino elements.

\subsection{Filling the space}

\subsubsection{Polycubes}

The laws of rhythmic repetition of geometric shapes in space are formulated by the science of geometry. We apply symmetry groups using different symmetry transformations during spatial repetition. Rotation around the axis passing through the lattice point is a typical symmetry transformation. There are five lattice systems in two dimensions, while in three dimensions, we know of seven. These lattice types can be cubic, tetragonal, orthorhombic, hexagonal, monoclinic, rhombohedral, or triclinic (Kittel, 1996, p. 10).

In search of the basic element of the optimal modular system, based on architectural traditions and gravity, this research starts with examining geometrical shapes (or Platonic shapes). According to Johannes Kepler's model of the Solar System, there are five geometric shapes in the three-dimensional space: he placed the octahedron inside, followed by the icosahedron, then the dodecahedron, the tetrahedron, and finally the cube (Barrow, 1996). 


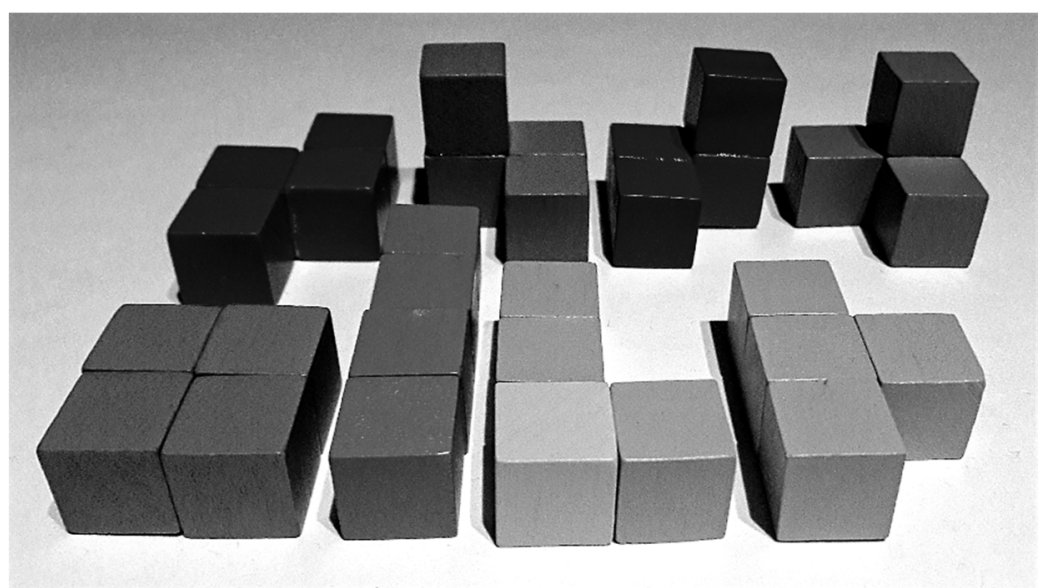

Figure 6: Tetracubes.

The most popular spatial logic game is made up of elements using identical cubic units. This game is called polycubes. The smallest system we can apply is the three-element tricube. There are two arrangements. The four-unit system of tetracubes can already be assembled in 8 ways (Fig. 6). These 8 elements consist of a total of 32 cubes, which are already sufficient for more complex spatial arrangements. Examining the possibilities, we can say that only two kinds of blocks can be built when using all the 32 cubes: there is a tower-like structure of $2 \times 2 \times 8$ units, and a $4 \times 4 \times 2$ flatter block.

Another approach is used in cases where we do not define the units or the number of the elements used, but the shape to be built. There are nearly 50,000 kinds of shapes possible to construct out of 27 cubes. The simplest of these is built from three cubes. However, if we allow two types of elements, we will get more interesting solutions. For example, if we use 6 tetracubes to build a 27-unit cube, there are 3 units left unfilled. Different solutions are obtained when all the elements are congruent, and when we exclude congruence. A full cube can be constructed by using 64 cubes. This cubic shape can be easily constructed using 16 arbitrary tetracubes (Lunnon, 1972).

\subsubsection{Soma cube}

Besides tangram, Soma cube is the most common logical puzzle game. In the 1930s, Piet Dein watched the drawings on the board during a lecture on quantum theory, representing 
cubes connected in different ways. Dein drew all three and four cubes so that they could create a single great cube, the cube of Soma.

The 7 basic shapes consist of a total number of 27 small cubes, which means that the edge of the Soma cube equals to three times the edge of the small unit cubes. The popularity of the game jumped in the 1960s with mass production. Computer modelling has shown that the construction of a three-unit-sided cube of the above elements is possible in more than 400 ways. Besides this, the game is perfect for constructing shapes including buildings, robots, animals, letters, or furniture (Fig. 7).

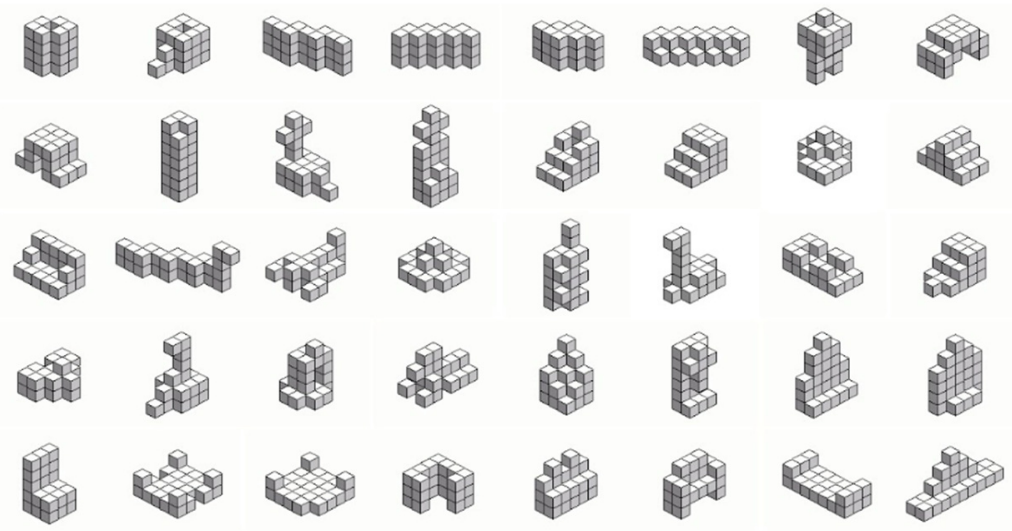

Figure 7: Spatial forms built from Soma cube units.

\section{APPLYING GEOMETRIC LOGIC SYSTEMS IN PRACTICE}

\subsection{Practical application of modular systems based on polycubes}

The space systems of the puzzles and their regularities provide a good basis for designing a modular housing system. However, it should not be forgotten that an architectural unit is considerably more complex than a simple logic game. In accordance with the previously listed needs and requirements, we examine the compatibility of the elements, the combinability of two or more elements, and the properties or character of the systems which we can build from the given elements.

Examining the compact apartment sizes of the metropolitan areas and the predicted processes of globalization in the subsequent decades, we have concluded that the minimum size of the housing unit in the urban environment can be modelled with the 
standard size of a shipping container $(6.06 \times 2.44 \times 2.60 \mathrm{~m})$. The basic unit corresponding to the module size of a standard shipping container can be subdivided, however, the functional unit itself needs to come up with full residential functions (living room, bedroom, kitchen, bath) in minimal scale and provide easy expansion and variation possibilities at the same time.

After further investigations, the original assumption was reconsidered, and we concluded that the height of a $6.06 \times 2.44 \times 2.60 \mathrm{~m}$ volume is oppressive. Its width is narrow to some extent, yet its length of $6.06 \mathrm{~m}$ is oversized in case of some basic functions (e.g., bathroom block, kitchen, bedroom, storage, etc.). However, a long prism can be less variable than a cube shaped unit. Thus, the size of the basic unit gets reduced to $3.00 \times$ $3.00 \times 3.00 \mathrm{~m}$, and this size determines the orthogonal grid allocation alike.

\subsection{Contextualization}

The selected area is located in Rákoskeresztúr, Budapest. The neighbourhood makes a transitional zone between the commercial units along Pesti Road with eleven-storey-high residential towers rising above the road and the family-owned, suburban residential area known as Birdhill (Fig. 8). The two L-shaped blocks are 5-storey-high, and face each other to encompass a spacious courtyard with a playground for kids.

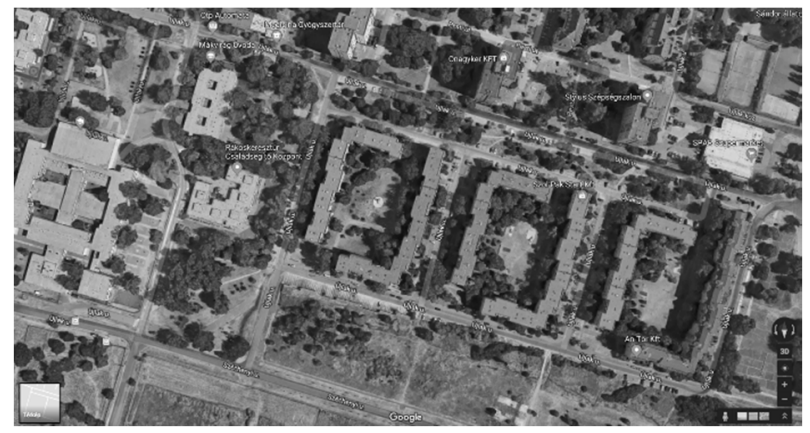

Figure 8: Bird's-eye view of the area. (Source: http://www.maps.google.com)

Taking the features of the site into account, the preliminary design goals, and parameters of the modular housing system, we distinguished two approaches: the narrow, ribbonshaped incorporation running along the roof $(83 \times 6 \mathrm{~m})$, and the smaller square-shaped extensions $(11 \times 11 \mathrm{~m}$ and $16.5 \times 11 \mathrm{~m})$ stretching between the staircases. Finally, we decided to combine the two versions. This decision is justified by the fixed-size system of the panel construction: according to this, the $3 \times 3 \times 3 \mathrm{~m}$ basic module, which was 
previously found to be optimal, got modified to a square-based column with $2.81 \times 2.81$ $\times 2.97$ m dimensions (Palócz, 2015).

In the version seen on Fig. 9, the $2.73 \mathrm{~m}$ grid follows the floor plan of the house, while the dwelling units wave in the middle tract with minor swings and interruptions. We started with an $8 \times 2 \times 2$ block constructed from tetracube elements already examined in the previous chapter. This block can further be divided into smaller blocks: $4 / 4$ divisions, $5 / 3$, and 4/3 splits are also possible (Fig. 10).

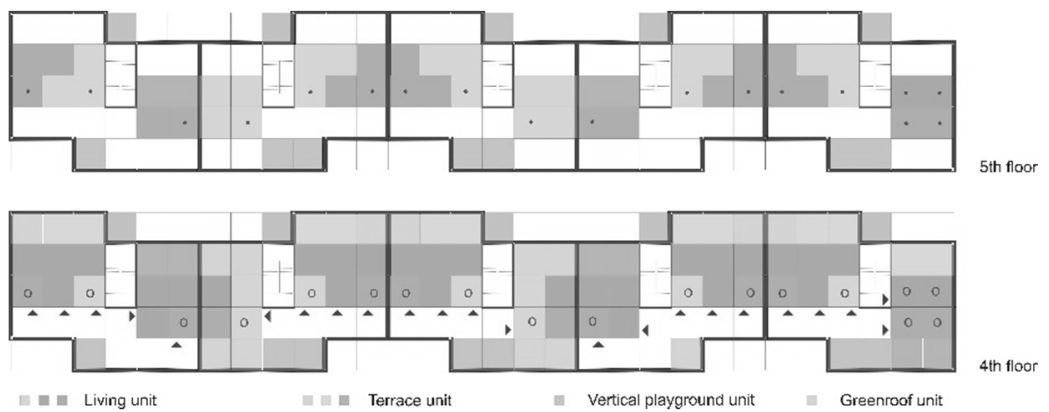

Figure 9: The intended use of flat roofs: ribbon-like, and rhythmic spatial arrangements.

Due to the modified dimensions, the floor area of the modules are reduced to $7.02 \mathrm{~m}^{2}$, therefore the tetracube elements provide up to $28 \mathrm{~m}^{2}$ of floor space, so it might be necessary to connect $2\left(56 \mathrm{~m}^{2}\right)$ or $3\left(82 \mathrm{~m}^{2}\right)$ tetracube elements in addition to studio apartments.

The concept of The Half of a Good House by Alejandro Aravena ${ }^{4}$ can be projected on this plan likewise: state aid applies to the construction of apartments of a specified size, while the empty modules of the grid can be utilized according to the needs of the inhabitants: new rooms, additional terraces, green roofs, winter gardens, vertical gardens as well as urban farm modules can be added (Perényi, et al., 2013).

\footnotetext{
${ }^{4}$ Alejandro Aravena's work, also known as social housing projects, is looking for and responding to the challenges of a global housing crisis. In 2004, with the help of the The Half of a Good House program in Iquique, Chile, 100 families got home from state support. Due to the scarcity of assets and lack of money and time, priorities had to be defined: they concluded that only one half of the houses would be built, and the residents would be able to integrate the unbuilt space of the house, depending on their own needs, possibilities and financial situation. The house is thus partly a state aid, partly through community cooperation, and partly with the active participation and active intervention of the inhabitants as a full-fledged but dynamically changing residential building (Winston, 2016).
} 


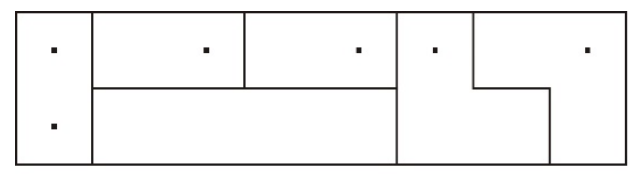

2nd layer

\begin{tabular}{|c|c|c|c|c|}
\hline 0 & 0 & 0 & 0 & 0 \\
\hline 0 & & & & \\
\hline
\end{tabular}

1st layer

Figure 10: The diagram of the $8 \times 8 \times 2$ block with the arrangement of tetracubes.

\section{CONCLUSION}

Studies have highlighted that, by the beginning of the 21 th century, the traditional role of architects has transformed: nowadays, architects' work involves the roles of cultural and social catalysts or educators. The purpose is no longer to improve the living conditions of an entire country, a city, or a neighbourhood, but to achieve positive, demonstrable changes in architectural design by encouraging conscious and responsible thinking in the local communities (Katona, 2018). We can distinguish between two overlapping areas: one that focuses on issues of local and social context, while the other is parallel to the global issues.

As an example for an issue of local context, the modular space system examined in the paper is able to perform subtasks through its flexibility, adaptive nature and hidden character (Zalavári, 2010). By reorganizing the space organizing elements, reinterpreting the formal and functional nodes, it creates new visual focuses that determine the life of the particular environment and community. It is also suitable for integrating different social strata that can act as a counterweight to the process of ghettoization. The modular housing systems also offer a new type of community platform: spatially dispersed units with dimensional and material changes can cover a number of community functions, thus encouraging the building of social relations between residents, the development of a local cultural community.

The goal of applying gamification in this context is to let the flexible system adapt to the characteristics of the neighbourhood, and to simulate the needs of the future dwellers. It also models the possible changes of family lives in a given time interval (McCall, et al., 2013). Besides focusing on design and floor area issues, it is also possible to make people more aware of energy use, $\mathrm{CO}_{2}$ emissions, water management, urban farming, recycling, 
community services, integration, etc. City One Game by IBM is an educational software designed to simulate the complexities of urban planning from water management to finance planning. ${ }^{5}$

In addition to the examined system, the concept also implies the following possibilities: the distortion of the basic unit, and the introduction of other shapes as basic elements of the modular systems. The results of this paper facilitate the examination and application of further alternatives.

\section{REFERENCES}

Barrow, J.D. (1996) The Artful Universe: The Cosmic Source of Human Creativity, Boston: Back Bay Books.

Bérczi, S. (1990) Szimmetria és struktúraépités (Symmetry and Structure Building), Budapest:

Tankönyvkiadó.

Cohen, J.-L. (2006) Le Corbusier, la planète comme chantier, Paris: Textuel.

Frampton, K. (1985) Modern Architecture: a Critical History, London: Thames and Hudson.

French, H. (2008) Key Urban Housing of the Twentieth Century: Plans, Sections and Elevations, London: W.W. Norton \& Company.

Gál, P. (2008) Ördöglakatok, pentominók és társaik (Mechanical Puzzles, Pentominoes, and the Like), Budapest: Typotex.

Gardner, M. (1991) Mathematical Puzzles and Diversions, London: Penguin Books.

Golomb, S.W. (1996) Polyominoes, New Jersey: Princetown University Press.

Gregotti, V. (1966) Il territorio dell'architettura (The Territory of Architecture), Milano: Feltrinelli.

Huizinga, J. (1949). Homo Ludens: A Study of the Play-Element in Culture, English trans., London: Routledge \& Kegan Paul.

Huotari, K. and Hamari, J. (2012) Defining Gamification: A Service Marketing Perspective, In: 16th International Academic MindTrek Conference [conference proceeding, Tampere, Finland, October 3-5, 2012, ISBN: 978-1-4503-1637-8], 17-22. https://doi.org/10.1145/2393132.2393137

Jeanneret, C.-É. (1923)Vers une Architecture, Paris: Éditions G. Crès et Cie.

Juul, J. (2003) The Game, the Player, the World: Looking for a Heart of Gameness. In: Copier, M. and Reassens, J., eds. Level-Up: Digital Games Research Conference Proceedings, Utrecht: University of Utrecht, 30-45.

Katona, V. (2018) A Search for Genuine Regionalism: A Regenerative Agenda for the Peripheries, In: Zaman, Q.M. and Troiani, I., eds. Transdisciplinary Urbanism and Culture: From Pedagogy to Praxis, Cham, Switzerland: Springer International Publishing AG, 213-226. https://doi.org/10.1007/978-3-319-55855417

Kittel, C. (1996) Introduction to Solid State Physics, New York: John Wiley and Sons.

Lee, B. (2017) Instant City: Living Air-Right: Affordable Housing in New York City, [online article], retrieved from: http://www.beomki.com/instant-city-living-airright .

\footnotetext{
${ }^{5}$ https://www-01.ibm.com/software/solutions/soa/newsletter/aug10/cityone.html
} 
Lenk, J. (2015) Kitagara Apartment Building by SAANA in Gifu, Japan, [case study, course ARC-541, Southern Illinois University, Spring 2015], retrieved from: https://static1.squarespace.com/static/5313b826e4b02a8d25126c66/t/552b1725e4b0c34422e 506f9/142 $\underline{8887333898 / 89607-85320+-+J a m e s+L e n k+-+F e b+27,+2015+159+P M+-+A 4-J a m e s+L e n k-K i t a g a t a-}$ Apartment-Housing-SANAA.pdf .

Lunnon, W.F. (1972) Symmetry of cubical and general polyominoes, In: Read, R.C., ed. Graph Theory and Computing, New York: Academic Press, 101-108. https://doi.org/10.1016/B978-1-4832-3187-7.50014$\underline{3}$

McCall, R., Louveton, N., Kracheel, M., Tigran, A., and Koening, V. (2013) Gamification as a Methodology: A Multi-Part Development Process, [workshop paper, CHI 2013 Workshop "Designing Gamification", organized by Gamification Research Network, April 28, 2013, Paris], retrieved from: http://gamification-research.org/wp-content/uploads/2013/03/McCall_etal.pdf .

Metz, T. (2003) MVRDV created Silodam, colorful waterfront housing built at the end of a wharf near the former silos for which it is named, Architectural record, 191, 3, 114-121.

Mitsuru, S. (1985) Minka: Kodansha Encyclopedia of Japan, Tokyo: Kodansha.

Palócz, K. (2015) Sustainable Solutions in Panel Rehab Housing Programs of Rákoskeresztúr, In: Székely, Cs., ed. Macroeconomic Decisions - Network Synergies: International Scientific Conference on the Occasion of the Hungarian Science Festival, [conference proceeding, November 12, 2014, Sopron, Hungary, ISBN: 978-963-334-203-9], Sopron: University of West Hungary (NYME), 60.

Perényi, T., et al. (2013) Többlakásos házak (Multi-apartment buildings), Budapest: BME Department of Residential Building Design.

Reiman, I. (1999) Parketták a geometria szemszögéből (Parquettes from the Viewport of Geometry), In: Molnár, F., ed. Matematikai mozaik (Mathematical Mosaic), Budapest: Typotex, 136-155.

Rodriguez, H. (2006) The Playful and the Serious: an Approximation to Huizinga's Homo Ludens, Game Studies, 6, 1, [ISSN: 1604-7982], retrieved from: http://gamestudies.org/0601/articles/rodriges .

Steward, C. (2006) Geometric Puzzle Design, Boca Raton, FL: CRC Press.

Wang, L. (2017) Penda unveils temporary nature-filled "village" for the Beijing Horticultural Expo, [online article, January 20, 2017], retrieved from: https://inhabitat.com/penda-unveils-temporary-nature-filledvillage-for-the-beijing-horticultural-expo .

Winston, A. (2016) Architects "are never taught the right thing" says 2016 Pritzker laureate Alejandro Aravena, [online article, January 13, 2016], retrieved from:

https://www.dezeen.com/2016/01/13/alejandro-aravena-interview-pritzker-prize-laureate-2016-socialincremental-housing-chilean-architect .

Zalavári, J. (2010) Hosszú élettartamú termékek tervezése (Designing Long-wearing Products), [DLA dissertation], Budapest: Moholy-Nagy University of Art and Design, retrieved from: http://konyvtar2.mome.hu/doktori/ertekezesek/DLAertekezes-ZalavariJozsef-2010.pdf . 